\title{
ATLA CONFERENCE JUNE 2012 TECHNICAL SERVICES
}

Tuesday, June 26

7:00-9:00pm

Interest Group

Technical Services Conversation: Acquisitions Practices - TSIG

Thursday, June 28

10:30-11:30am

Conversation Groups

CONSER

10:30-11:30am

Papers

Technical Services Assessment: Help for Navigating the Wilderness

11:30am-1:00pm

NACO Lunch- FUNNEL MEMBERS ONLY

2:00-3:30pm

In-Conference Workshop

Macro-Economics: Saving Time (and Money) by Using Macros in Cataloging - TSIG

4:30-5:30pm

Interest Groups

Cataloging with MarcEdit - TSIG

Friday, June 29

9:00-10:30am

Panel

Mass Migration: Moving 3 Million Records and 200 Library Staff to a New ILS

11:00am-12:00pm

Conversation Groups

NACO

4:00-5:30pm

In-Conference Workshop

eBook Records: the Good, the Bad, and the Ugly - TSIG

Saturday, June 30

8:30-10:00am

THEOLOGY CATALOGING BULLETIN 
In-Conference Workshop - CPAL Interest Group

Digital Information: An Introduction for Librarians and Archivists

1:00-2:00pm

Conversation Groups

e-Books, e-Readers, e-Resources, Oh My! What's a Small Theological Librarian to Do?

\section{LIBRARY OF CONGRESS' IMPLEMENTATION OF RDA}

The Library of Congress has set March 31, 2013 as its target for RDA Implementation Day One. Some of LC's partner national libraries (U.S.: National Agricultural Library and National Library of Medicine; and non-U.S.: British Library, Library \& Archives Canada, and National Library of Australia) have targeted the first quarter of 2013.

http://www.loc.gov/catdir/cpso/news rda implementation date.html

\section{TRAINING PRESENTATIONS, WEBCASTS, AND WEBINARS}

Library of Congress Recorded Webcasts for RDA Training

RDA: Looking to the Future: Information Systems and Metadata. Speaker: Barbara Tillett.

Recorded March 9, 2010.

RDA Changes from AACR2 for Texts. Speaker: Barbara B. Tillett. Recorded January 12, 2010. Running time: 75 minutes (41 minutes of presentation followed by Q\&A).

RDA: Recursos Descripción y Acceso: Antecedentes y Aspectos de su Implementación. Speaker: Barbara Tillett. In Spanish. Recorded August 13, 2009. Running time: 85 min.

Georgia Public Library Cataloging Summit http://www.loc.gov/aba/rda/Georgia training aug 2011.html

Library of Congress RDA Training Exercises and Answers http://www.loc.gov/aba/rda/training exercises.html 